\title{
Online Assessment Effect in EFL Classroom: An Investigation on Students and Teachers' Perceptions
}

\author{
Ima Fitriyah'1, Miftahul Jannah² \\ ${ }^{1}$ IAIN Kediri, Indonesia.E-mail: imafitria@iainkediri.ac.id \\ 2Universitas Muhammadiyah Pringsewu, Indonesia.E-mail:mjanne@umpri.ac.id
}

\begin{tabular}{|c|c|}
\hline ARTICLE INFO & ABSTRACT \\
\hline $\begin{array}{l}\text { Keywords: } \\
\text { assessment for learning, } \\
\text { effects, online language } \\
\text { assessment }\end{array}$ & $\begin{array}{l}\text { The teaching and learning process changed into an online during the COVID- } \\
\text { 19 outbreak, and thus online evaluation became a requirement. This research } \\
\text { examines the positive and negative effects of online assessment on students' } \\
\text { learning behaviour and how teachers prepare their teaching. This case study } \\
\text { research included the result of questionnaire from thirty IC students followed } \\
\text { by interview with three EFL teachers in the Intensive English Course (IC) } \\
\text { program and six IC program students in one of Islamic University in Kediri. The } \\
\text { small survey indicated that students have positive attitude toward the } \\
\text { administration of online assessment. Furthermore, the outcomes of open- } \\
\text { ended interviews showed that there were four themes for beneficial effects, } \\
\text { including enhancing flexibility in assessment, improving evaluation } \\
\text { versatility, building teachers and students'awareness of preparing evaluation } \\
\text { and cultivating students' autonomous learning abilities. On the other hand, } \\
\text { three themes for negative effects emerged from the online assessment, } \\
\text { including complication of evaluation administration, reduced interaction } \\
\text { between teachers and students, and anxiety in English test. The effects } \\
\text { emerge from how teachers and students view the drawbacks of the online } \\
\text { assessment itself. Positive effects lead to students'learning better are caused } \\
\text { by lesson taken from conducting the test; however, the negatives should be } \\
\text { treated as challenges that will improve the teaching and learning. Finally, } \\
\text { both teachers and students are ready to face online assessment in the future. }\end{array}$ \\
\hline \multicolumn{2}{|c|}{$\begin{array}{l}\text { How to cite: } \\
\text { Fitriyah, I. \& Jannah, M. (2021). Online Assessment Effect in EFL Classroom: An Investigation on Students } \\
\text { and Teachers' Perceptions. Indonesian Journal of English Language Teaching and Applied Linguistics, 5(2), } \\
265-284 \text {. }\end{array}$} \\
\hline
\end{tabular}

\section{Introduction}

The topic of language assessment has never gone unnoticed by scholars. The impact of assessment on teaching and learning has received much attention in the literature (Furaidah et al., 2015; Galikyan et al., 2019; Johnson \& Shaw, 2019; Xu \& Liu, 2018). Language evaluation has gained traction in online learning as the development of increasingly sophisticated learning technologies. Additionally, when its execution has to be online, the 
effect of online assessment for EFL learning has become increasingly important research content. The topic of the effect of assessment is still relevant in this rapidly changing, as many experts argue that the mechanism of language teaching and learning has a causal connection with the evaluation. Recently, the implementation of online learning along with assessment resources also find their momentum (Ali, 2015; Cai, 2012; Daniels et al., 2019; Doculan, 2016). And thus, the effect may occur differently between online assessment and non-online assessment.

The effect of assessment can be either positive or negative (XU and Liv, 2018). It occurs as the consequence of doing test. A positive effect emerges when the test is well constructed and assesses what to be assessed. Meanwhile, the negative effect occurs for some reasons; since language teaching is influenced by a complex of social psychological, political, technological, and data-driven accountability factors in which evaluation and teaching are rooted (Ali and Hamid, 2020; Furaidah et al., 2015). These effects can occur regardless of whether testing is conducted in one technical mode or another (e.g. paper-based to online testing)(Cox et al., 2018). In addition, online formative and summative appraisal comparative analyses struggle with test behavior such as test confidence, anxiety level (Cassady and Gridley, 2005), and student involvement (Han and Finkelstein, 2013).

According to Spivey and McMillan (2014), online testing has many advantages over traditional paper-and-pencil testing. First, online evaluation allows for adjustable testing cycles in which the test can be conducted. Second, online software can be set up to automatically randomize the order of questions as well as the set of responses for multiplechoice and matching questions. Third, different levels of feedback, such as a test score, a test score with accurate answers, or a test score with detailed solutions, may be provided. Teachers also have power over when and how input is given (e.g., immediately, set to a particular date and time after all questions are completed). Fifth, it is possible to set up preferred online testing systems to include clues or prompts as to where the text or course notes will find support to answer a question. Spivey and McMillan (2014) also assert that the assessment protocol has little impact on study activities or course results. The writers, on the other hand, discovered a close correlation between students' effort and their course results. Similarly, Mohamadi (2018) argues that integrating engaging technologies and methods with appropriate assessment tools is a successful way to enhance learning performance. More specific, Johnson and Shaw (2019) believe that the development and deployment phases of a computer-based test (CBT) project are inextricably related, with the washback system playing a key role in taking these elements together.

Assessment for learning (AfL) in formative assessment, as opposed to assessment of learning (AoL) in summative assessment, has arisen as a novel term in recent debates on tests (Hill and McNamara, 2011). In accordance with the changes in learning theory, assessment has also experienced a transition from assessment of learning (AoL) to AfL (Lee \& Coniam, 2013), which allows teaching professionals to switch from evaluation for qualification and accountability purposes to a forum through which learners participate in self- and peer evaluation and build critical knowledge through formative awareness. Learning is a goal in the AfL process, and assessment is a tool for achieving that goal (Lee, 2007). Rather than dwelling on how to measure students' success, teachers must combine teaching, studying, and evaluation while implementing AfL. In AfL, assessment is important in improving and expanding students' independent study. Understanding the connection between teaching 
and learning, as well as how assessments can be used to inform teaching and learning, is the first step in implementing AfL.

The study on how online tests affect not limited to the high-stakes test but also to classroombased assessment. However, the effect of classroom-based assessment cannot be separated from the idea of high-stakes test. How high-stakes test effect, known as washback, on students' learning behaviour have been investigated (Galikyan et al., 2019; Kilickaya, 2016; Zhan \& Andrews, 2014). Some other studies put their finding on national exam washback (Furaidah et al., 2015; Sundayana et al., 2018). They found that the ENE (English National Exam) had a major effect on the students' emotions and attitudes, on the teachers' perspective, and the school preparation. Similarly, Wang et al., (2014) investigated highstakes testing to assess the true washback of the Internet-Based College English Test Band 4 in China, and they learned that the test's real impact on students' learning was their autonomy. Baksh (2016) investigated the washback impact on students learning attitude in smaller scale; School-based English Language Assessment. External examinations and School Based Assessment (SBA) were also negative among the students polled. In a smaller scale, Şenel \& Tutunis, (2013); Suryoputro, (2016); Wihastyanang and Latief, (2018) revealed students' perception on the washback in reading and the impact of electronic feedback on students' writing. The result indicated that electronic feedback is not practical since students' different learning styles and some technical factors, like facilities and infrastructure. Finally, some others made a review on the study of washback (Cheng et al., 2015; Green, 2013; Hakim, 2018; Johnson and Shaw, 2019).

Investigating whether immersive online platforms in language evaluation improve students' learning levels is a fruitful research area that is missing from the above studies. Although online learning is becoming more common in developed countries, it is still in its infancy in developing countries. This research is critical in situations where novel assessment arrangements are being applied and evaluated. Many of paper-based tests and assessments have been shifted into an online one since the learning changed into an online one. Indonesian EFL teaching-learning is required to transform into online with some shortcomings. Not all Indonesian students can afford the current technology, such as internet connection easily. The education policymaker should understand the effects that emerged on the use of such test on aspects related to teaching-learning activities. The assessment which has been conducted by a teacher may emerge as a positive or negative effect for the students, teacher, curriculum, and the institution. Conversely, most studies investigated high-stakes, standardized tests, entrance tests, and classroom-based test on students' feelings and learning attitude; a scant investigation on the effect of alternative assessments, like e-portfolio assessments or online assessment on how it gives impact to students, teachers, test designer, and curriculum maker. Since the major dimensions of assessment effect include the learners, teachers, materials, and wider impact of the test (Green, 2013; McKinley \& Thompson, 2018), further studies should consider the effect that may emerge in online language assessment for those who are concerned with as suggested by Green (2013). The study's results raise the issue of whether an alternate evaluation, such as an online assessment, may have a positive or negative impact on students' learning and teaching practices. The main questions which lead the following study are 1) what is the actual effect of online assessment in EFL classroom? 2) How do the positive and negative effects emerge 
from online assessment in the EFL classroom? and 3) How does the effect affect students and teacher readiness in preparing for the online teaching and learning process?

\section{Literature Review}

\subsection{Online Assessment}

Recently, educators have introduced an online examination that complements the conventional paper-and-pencil exam. During the COVID-19 outbreak, schools from home allow teachers to perform complete online evaluations due to enforcement of physical and social distancing. Assessment deals with tests and activities, assessing the success of the students to decide whether to pass such a topic or only part of it. However, in the form of an exam, this is not limited to awarding scores, certificates, or any other form of qualification to learners. "Instead, evaluation persists throughout the learning process and may include teacher observation, learning discussions, group collaboration, and educational or training work analysis" (Hricko \& Howell, 2006, p. 49). An online assessment is not only facilitated by the evaluation process, but also by opening up tools that are not accessible in the face-toface environment (Benson \& Brack, 2010).

Benson and Brack (2010) argue that it takes a clear focus on the purpose and aims of the evaluation and the basic principles of evaluation design to make decisions on whether, when, or how to use online evaluation in teaching. In order to help the online evaluation, teachers should also recognize the availability of technology (e.g., instruments and internet connection). There are four major online appraisal categories (both formative and summative) suggested by Benson and Brack (2010) that provide opportunities for reconceptualization to improve authenticity. The use of an online evaluation environment is shown in Table 1.

Some of the large issues relating to online evaluation management, on the other hand, have been discovered. Benson \& Brack (2010) divided the problems into four aspects, including student assistance, technological problems, authentication/plagiarism, and administrative skills of the instructor. Students help deal with questions of access and fairness, and instruction criteria (expectation, logins, and troubleshooting). Some families can afford a laptop to access the online examination, and others who cannot. Each student has different family backgrounds. In performing online evaluations, teachers as assessors should provide consistent instruction and guidance because students may often feel inhibited in seeking clarification in a completely online environment. Factors usually deal with accessibility to suitable hardware and software in technological matters. Often it is not possible to help the device's program to access online tests. Setting up evaluations, service disruption, and bandwidth are also technological challenges. Authentication/plagiarism in online evaluation is the third risk factor. Due to a lack of supervision in online examination, students may steal, conspiracy and plagiarism. An online examination requires students to take the test anywhere and has not been designed to allow open access to their text and notes (Spivey \& McMillan, 2014). The last factor is the management skills of the teacher. Teachers need to be able to use software (download, mark, and upload items), handle grades, and provide assistance to perform successful online evaluations. 
Table 1. Uses of Online Environment for Assessment

\begin{tabular}{|c|c|}
\hline Uses & Examples \\
\hline $\begin{array}{l}\text { 1. Submission of items for } \\
\text { assessment }\end{array}$ & $\begin{array}{l}\text { - Essays: discursive, descriptive, } \\
\text { analytical } \\
\text { - Reports: CBL, PBL } \\
\text { - Reviews: critical, analytical } \\
\text { - } \text { Media: image, audio, video, } \\
\text { presentation }\end{array}$ \\
\hline $\begin{array}{l}\text { 2. Automated assessment } \\
\text { - Quizzes } \\
\text { - Multimedia }\end{array}$ & $\begin{array}{l}\text { - Multiple choice } \\
\text { - Short answer } \\
\text { - Calculation } \\
\text { - Matching } \\
\text { - Fill blanks } \\
\text { - True False } \\
\text { - Drag and Drop } \\
\text { - Simulations } \\
\end{array}$ \\
\hline 3. Online discussion & $\begin{array}{l}\text { - Forums: case analysis, project } \\
\text { development } \\
\text { - Debates } \\
\text { - Allocated roles: lead, summarise, } \\
\text { provoke } \\
\text { - Roleplays }\end{array}$ \\
\hline 4. Web publishing & $\begin{array}{l}\text { E-portfolios } \\
\text { - Webpages: blogs, wikis } \\
\text { - Shared documents: google } \\
\text { documents }\end{array}$ \\
\hline
\end{tabular}

\subsection{Aassessment for Learning (AfL) in EFL Classroom}

The term AfL, which is often interchangeably used for formative evaluation, differs from AoL, which involves summative evaluation. As a consequence, the AfL-AoL distinction is close to the long-standing distinction between formative and summative assessment purposes (Lee, 2007). The object of summative assessment is for administrative and reporting purposes (Genesee \& Upshur, 1996), while formative assessment contributes to students learning by supplying performance information (Yorke, 2003).

This report's use of AfL highlights the value of learning in the classroom. It is described as the process of collecting and evaluating information for learners and teachers to use in deciding where they are in their learning, where they need to go, and how to get there (Assessment Reform Group, 2002). Key principles of AfL proposed by the Assessment Reform Group $(A R G) ; 1)$ Sharing learning goals with students, 2) assisting students in recognizing the objectives they are moving against, 3) engaging students in testing, 4) teachers giving positive input, and 5) promoting a classroom atmosphere in which mistakes are a common part of learning and everyone will improve. 


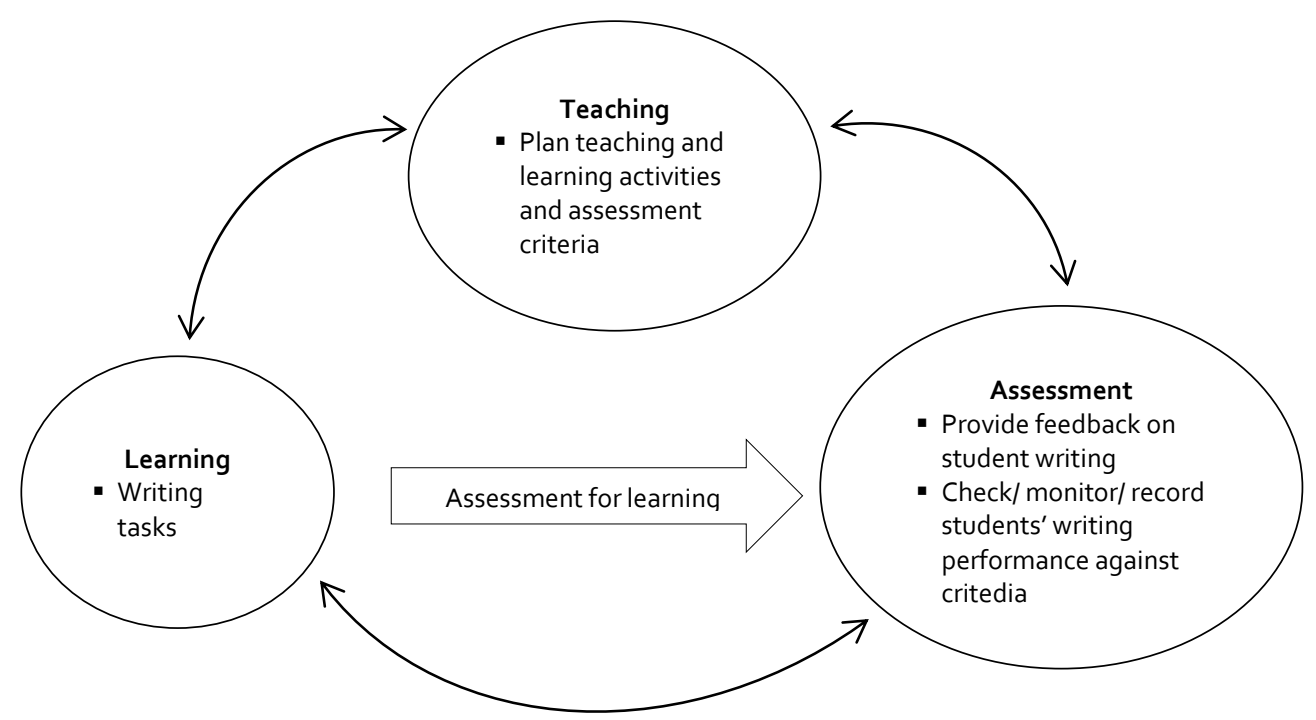

Figure1.Interrelationships between teaching, learning and assessment

There are ten other principles, according to the ARG, that the AfL solution must be based on (Assessment Reform Group, 2002). The ARG claims AfL should: 1. Being part of effective teaching and learning planning; 2 . Concentrate on how students learn; 3 . Be remembered as fundamental to practice in the classroom; 4. Be known to teachers as a core technical skill; 5 . Be sensitive and positive because there is an emotional effect to any evaluation; 6 . Take note of the value of inspiration for learners; 7. Foster adherence to learning outcomes and a common view of the standards on which they are evaluated; 8 . Provide positive feedback to learners on how to improve; 9. Improve the self-assessment skill of learners so that they can become analytical and self-managing; 10 . Recognize all learners' broad spectrum of achievement.

\section{Research Methodology}

\section{a. Research Procedure}

This research seeks to examine the influence of online assessment in the Intensive English Course (IC) program, as well as how students in IC courses view online assessment and how students and teachers use it (assessment for learning). This research uses a qualitative approach to concentrate on input from assessment for learning for teachers to improve their teaching strategies and for students to enhance their learning strategies in order to meet the study's goals. The data was gained from the in-depth interview with students, supported by the result of the questionnaire distributed to the students, and teachers of IC program. The online test is midterm test of IC after two months of students' learning and seven times online quizzes. Learning from the result of the study, it is expected to be able to be used as a basis for teachers and students to make their teaching and learning process better after knowing students' attitude toward the online assessment.

\subsection{Participants}

Students of IC classes at the first semester of English department in one of Islamic university in Kediri are the participants. The students are placed into six groups of IC program consist of 
160 students. All the students get the same treatment since the team-teaching technique is applied to the classes. The present study aims to gain students' attitudes regarding the effect of the online midterm test, for it is the first higher-stake assessment they had during the lessons since they are in the university. Thirty students are involved in the questionnaire session, and six IC students and three instructors are involved in the process of data collection through in-depth interview.

\subsection{Instruments}

The design of the questionnaire and interview guide was based on a review of the conceptual framework of washback (Alderson \& Wall, 1993; Bailey, 1996) and adopted from Fan et al., (2014) and Cheng et al., (2011). In this study, learning practices are operationalized as three dimensions near related to students' learning processes: learning attitudes, learning content, and test preparation strategies. These instruments were used to answer research questions: the actual effect in students' learning and how it emerges from the online assessment. The questions in the questionnaire were generated from five main themes as follows: (1) Students' attitudes of the effect of online assessment in IC program with six statements; (2) Students' perception of the content of online assessment in IC program with eight statements; (3) Impact on the learning attitudes with five statements; (4) impact on learning content with four statements; (5) impact on test preparation strategies with seven statements. The anonymous students' surveys elicited the opinions of the students on the use of online assessment. The instrument comprising five Likert-type items. All the Likertscale items were analyzed in terms of percentages.

When the data from questionnaire was obtained, in-depth interview was done to get thorough information of students and teachers' experience and reflection on the issue. Indepth interview was applied for it is not entirely limited, nor non-directive, by a list of standard questions. It is aimed to gain more information about the conditions of the interviewees and to explain or extend their responses using prompts, probes and follow-up questions. In conducting the in-depth study on the effect of online assessment, interview guide was employed. The interview guide was used to gather data regarding the effect of the online test in the IC program on students' learning, perception of online assessment, and how to get advantages of the online test in the teaching and learning process. Moreover, the interview section was used to gain data on how the effect affects students' and teachers' readiness to prepare for the online teaching and learning process. The interview guideline with students covers students' perceptions of the online test in the IC program and its effect on students' English learning. In the same fashion, the interview guide with the teacher cover three primary information; how students online test result, how the online test for IC in terms of design, administration, scoring, etc. and the impact of the online test, if any, on English teaching practices.

Table1. Blueprint of the interview guide

\begin{tabular}{|c|l|}
\hline No & Indicators \\
\hline 1 & Effect types (advantages and disadvantages) \\
\hline 2 & Factors that make effect emerge \\
\hline 3 & Students' perceptions of the online assessment in IC Program \\
\hline 4 & Impact on learning attitudes/motivation \\
\hline 5 & Impact on learning content \\
\hline 6 & Impact on test preparation strategies \\
\hline
\end{tabular}




\subsection{Data Analysis}

All the Likert-scale items of the questionnaire were analyzed in terms of percentages. The review of the data collected from the interview is carried out in two major stages. Firstly, the interview data are transcribed and interpreted through topological analysis in relation to the responses of the students to washback, interpretation, and the way to use the IC program's online evaluation. Secondly, the frequency of the data relevant to the questionnaire is determined, showing to what degree the students generated answers and opinions regarding the effect of the IC online assessment.

The Indonesian language was chosen as the language to execute the interview processes in order to facilitate the participants in furnishing the suitable and constitutive details with regard to the focused data. Each process of the interview was digitally recorded thourg WhatsApp chat to assist the researcher in data transcription. It is used to clarify whether or not what is obtained from the interview is appropriate to what the research subjects meant. So-called as member checking, this step was also done to pursue the degree of trustworthiness.

Using Hashimov" (2015) interactive data analysis model, the collected data was analyzed. Data selection, data reduction, data show, and data conclusion drawing are the procedures. The interview was used to gather data in the form of knowledge with regard to the common experiences of teachers and students in an online test. The entire data collected has been systematically categorized in the process of data reduction. The grouping was based on coded themes to reflect any compulsory data related to the problem of the study. The specifics of the interview transcripts were also discussed. The result of the study on how effects of online test is expected to be new insight to administer appropriate assessment for EFL students. Moreover, even though the test is carried out online, the test results can also be used as a reference to improve the teaching and learning process. It can also be called online learning outcomes that can reinforce one view that the proper assessment is an assessment for learning, not an assessment of learning.

\section{Findings and Discussion}

Findings from questionnaire about online assessment effect on students are shown in the table below.

Table 1: The result of questionnaire

\begin{tabular}{|c|c|c|c|c|c|}
\hline Items & $\begin{array}{l}\text { Strongly } \\
\text { Disagree }\end{array}$ & Disagree & Neutral & Agree & $\begin{array}{l}\text { Strongly } \\
\text { Agree }\end{array}$ \\
\hline I feel nervous when doing my online test for IC & & & $43,3 \%$ & $30 \%$ & \\
\hline I feel confidence in doing the online test for IC & & $20 \%$ & $40 \%$ & & \\
\hline $\begin{array}{l}\text { Doing the test without direct teachers' } \\
\text { supervision (online), make me nervous }\end{array}$ & & $36,67 \%$ & $26,67 \%$ & & \\
\hline $\begin{array}{l}\text { The platform of IC online test makes me } \\
\text { nervous }\end{array}$ & $33,3 \%$ & $43,3 \%$ & & & \\
\hline $\begin{array}{l}\text { I am not confidence in doing the test because } \\
\text { of my internet connection }\end{array}$ & & $40 \%$ & $33,3 \%$ & & \\
\hline $\begin{array}{l}\text { Test instruction is well understood so that I } \\
\text { can do the test without feeling anxious }\end{array}$ & & $46,67 \%$ & $20 \%$ & & \\
\hline Test design is on the whole satisfactory & & $53,3 \%$ & $16,67 \%$ & & \\
\hline Test result truly reflect my English proficiency & & & $30 \%$ & $50 \%$ & \\
\hline
\end{tabular}


Online Assessment Effect in EFL Classroom

\begin{tabular}{|c|c|c|c|c|}
\hline The level of difficulty of the test is appropriate & & $40 \%$ & $33,3 \%$ & \\
\hline $\begin{array}{l}\text { Objective and subjective questions/items are } \\
\text { well balanced }\end{array}$ & & $60 \%$ & $30 \%$ & \\
\hline $\begin{array}{l}\text { Language skill tested in listening are what I } \\
\text { need }\end{array}$ & & $46,67 \%$ & $36,67 \%$ & \\
\hline $\begin{array}{l}\text { Language skill tested in reading are what I } \\
\text { need }\end{array}$ & & & $56,67 \%$ & $26,67 \%$ \\
\hline $\begin{array}{l}\text { Language skill tested in speaking are what I } \\
\text { need }\end{array}$ & $26,67 \%$ & & $53,3 \%$ & \\
\hline $\begin{array}{l}\text { Language skill tested in writing are what I } \\
\text { need }\end{array}$ & $16,67 \%$ & & $43,3 \%$ & \\
\hline $\begin{array}{l}\text { I have paid more attention to English by } \\
\text { taking IC course }\end{array}$ & & & $63,3 \%$ & $16,3 \%$ \\
\hline $\begin{array}{l}\text { IC online assessment has improve my interest } \\
\text { in English }\end{array}$ & & $46,67 \%$ & $26,67 \%$ & \\
\hline $\begin{array}{l}\text { IC Online assessment has improved my } \\
\text { confidence in English }\end{array}$ & $33,3 \%$ & $26,67 \%$ & & \\
\hline IC online test makes me more active in English & & $30 \%$ & $23,3 \%$ & \\
\hline $\begin{array}{l}\text { I have spent more time on English by taking IC } \\
\text { online test }\end{array}$ & & & $60 \%$ & $20 \%$ \\
\hline $\begin{array}{l}\text { Because of IC online test, I listened more on } \\
\text { English program }\end{array}$ & $16,67 \%$ & & $53,3 \%$ & \\
\hline $\begin{array}{l}\text { Because of IC online test, I watched more } \\
\text { English videos }\end{array}$ & & & $46,67 \%$ & $16,67 \%$ \\
\hline $\begin{array}{l}\text { Because of IC online test, I read more English } \\
\text { books }\end{array}$ & $46.6 \%$ & & $30 \%$ & \\
\hline $\begin{array}{l}\text { Because of IC online test, I have more } \\
\text { speaking activities }\end{array}$ & $23,3 \%$ & & & \\
\hline $\begin{array}{l}\text { I prepare myself well to face the online test of } \\
\text { IC program }\end{array}$ & $26,67 \%$ & $33,3 \%$ & & \\
\hline $\begin{array}{l}\text { To prepare the online test, I have set English } \\
\text { learning goals }\end{array}$ & & $36,67 \%$ & $30 \%$ & \\
\hline $\begin{array}{l}\text { To prepare the online test of IC, I have made } \\
\text { study plans }\end{array}$ & & $53,3 \%$ & $16,67 \%$ & \\
\hline $\begin{array}{l}\text { To prepare the online test of IC, I have often } \\
\text { reviewed lessons }\end{array}$ & & $50 \%$ & $23,3 \%$ & \\
\hline $\begin{array}{l}\text { To prepare the online test of } I C, I \text { have } \\
\text { managed my time better }\end{array}$ & $30 \%$ & 26,675 & & \\
\hline $\begin{array}{l}\text { I have tried to find a good learning method for } \\
\text { IC online test }\end{array}$ & & & $43,3 \%$ & $26,67 \%$ \\
\hline $\begin{array}{l}\text { I have tried to change my learning habit for IC } \\
\text { online test }\end{array}$ & & $30 \%$ & $46,67 \%$ & \\
\hline
\end{tabular}

The finding from the questionnaire indicates that most of the students have a good preparation for their online assessment. They become more independent and have more autonomy in learning. The last seven items show that IC online assessment has made students prepare for the test indicated by the high percentages for the agree and strongly agree on Likert scale. Moreover, the finding also shows how students had less anxiety facing online assessment in IC program as shown by first seven item on the questionnaire of online assessment effect. These findings are in line with Lee (2007). Learning is a goal in the AfL process, and assessment is a tool for achieving that goal (Lee, 2007). Finally, this finding is in contrast with the finding of research done by Cassady and Gridley (2005). Online formative 
and summative assessment comparative analyses struggle with test behavior such as test confidence, anxiety level (Cassady and Gridley, 2005), and student involvement.

Following the result from the questionnaire, here are the outcomes of the interview after being transcribed and interpreted through topological analysis in relation to the responds of the teachers and students to the online assessment, interpretation, and the way to use online evaluation for teaching and learning. The result of the analysis is then grouped to answer research question 1,2 and 3 .

\subsection{The actual effect of online assessment in EFL classroom}

The findings to answer the first research question can be classified into two, positive and negative effects of online test on IC teaching and learning process. Cheng et al. (2004) argued that once teachers and learners have a positive attitude and work effectively and collaboratively towards assessment and learning goals, positive effects will arise. In this study, positive effects from the online assessment were discovered; enhancing the flexibility of assessment (an online assessment allows students to take the test anywhere and was not proctored enabling open access to their text and notes), building awareness of preparing online language assessment and improving language assessment knowledge. On the other side, some negative effects can be seen from the complication of assessment administration, lower of teachers and students engagement and interaction, frustration with technology, anxiety in language test and lift students' motivation. The discussion of each effect is elaborated as follows;

\section{Enhancing the flexibility of assessment}

Both teachers and students believed that online assessment is more flexible rather than a classroom or offline assessment. Flexibility here was dealing with time and space. The finding was in line with Spivey and McMillan (2014) who proposed online assessment allows adjustable testing times and the dates during which the test may be conducted. The following excerpts from the interview describe the teacher and students' perceptions of the online assessment flexibility:

T1: "It is flexible, direct data stored, easy grading, students can immediately see which answers are right and wrong..."

S1: "The advantage is that I still be able to do homework because it is online, I have lot of time to finish my work"

Teachers felt that online assessment gives much more time for them to assess. They could check the student's work every time and everywhere. It was easier for the teachers to look back into student's work if they felt that the work needed to be reviewed once again. Teachers admitted online assessment becomes a preference for its flexibility. This is in agreement with (Cassady \& Gridley, 2005; Spivey \& McMillan, 2014). They noted that depending on the form of delivery selected by the teacher, the benefits of offering course tests online can include versatility in presenting tests to students and efficiency in scoring. Students are not inherently constrained by conventional artificial academic schedule limitations when taking exams online. 


\section{Building awareness of preparing online language assessment}

Both teachers and students are in one idea that they have to prepare well before conducting the assessment.

T1: "I like this ... I don't know what to do ... because this is online so it's challenging, especially preparation and correction, maybe the improvement is in the way they don't know where they should write instead of typing (but because of online) ... because writing skills according to me is different from typing skills ... improvements for lecturers ... it is much more likely to give training on the problem ... make group discussions outside of the classroom too ... it's hard but we must do that"

T2: "It takes longer to develop and prepare the test, yet it is very easy to grade when it is multiple choice test"

As has been observed by the researcher herself and based on the review, IC teachers have conducted several meetings concerning the online test preparation. The preparation is more on the English language test development. As the administration is $180 \%$ different from the previous IC class, six teachers struggled to develop appropriate tests. Conducting essay integrative test was hard to be done, then objective tests were the alternative. But then, as mentioned before, it takes longer to develop and prepare the test. However, the grading benefits more for them. This finding has a contrasting idea with what (Xu \& Liu, 2018) found. If the teachers of IC has intense preparation which indicates that IC online test has an intense effect on teacher preparation, $\mathrm{Xu}$ and Liu (2018) found that about a quarter of those who prepared students for the TEM (Test of English Major) used the lecture style, whereas the majority of those who prepared students for TEM in their classrooms spent no more than 10 hours on TEM training, indicating that the washback of TEM on course design is not intense.

S2: "Language abilities tested in reading are what I need and the IC class should be foucusing on the other skills in English. It should be focused on listening, speaking, reading and writing. Because those components are related in the English skills not only in grammar or writing ( if I might add some suggestions especially for writing, the students should write their own masterpiece like making a story or etc). They can write based on the tenses they have learned, I mean to make a variant in teaching and learning progress".

On another side, students were also aware of how to prepare tests in online assessment. The student's opinion indicated the result of the assessment could be a good input for the teaching and learning process. The result is inline with what Lee, (2007) inquiries. He emphasized on how feedback from the assessment gives benefits on students' writing, especially in assessment as learning.

\section{Cultivating students' autonomous learning abilities}

Learners' autonomy is thought to assist students in optimizing their learning outcomes by increasing their knowledge of their own learning paths. One of the students mentioned: 
S4: “... added learning from various sources such as the internet, other books, not just one book. If the score is good, I will not be satisfied quickly, if possible, it will be better and be maintained. The point is I will try to be better than yesterday. The test results will always motivate me not only to increase my mid test score, but also my understanding..."

Although not all students' mention their ways in learning, three of the participants admitted that online learning and online language assessment improve their autonomous learning significantly. Learner autonomy refers to students' desire to take charge of their own learning. This idea is assumed to allow learners to become more involved and successful language learners. By knowing students own mistakes and deficiency, they become aware in making themselves better learners. This is in agreement with Rahman, (2018) " setting clear goals for learners and helping them to evaluate their clear goal help them become autonomous". Alderson and Wall, (1993) and Bailey, (1996) also clarify that the effect of a test is more on personal rather than collective individual.

Moreover, the data obtained from the interview revealed that there was a teacher who explained that not all of her students become unmotivated because of the online assessment. High learning motivation could lead to autonomous learning. Yet, decreased motivation was caused by external factors dealing with technology:

T1: "Not all of the students have low motivation toward online assessment. Some students faced difficulties because they did not have mobile phones, they should use their parents' mobile phones. Even their parents also work outside, so they had to wait for them. On the other hand, some of them were excited about online assessment."

$\mathrm{S1}$ : "I personally think that this online test spurred my enthusiasm for learning, especially when I encountered questions that I had not been able to solve or that I had not yet understood, and became the main driving force for students to study hard in order to produce maximum scores".

This finding is inline with the research comes from $\mathrm{Ha}$, (2019) and Wang et al. (2014). Wang et al. (2014) investigated high-stakes research to determine the true washback of the Internet-Based College English Test Band 4 in China, and they discovered that the test's real impact on students' learning was their autonomy.

\section{Improving language assessment knowledge}

The teachers needed to develop language assessment by considering whether the assessment tasks accommodate variant learning styles and abilities, whether the workload is appropriate, or whether the assessment is fair and has equality for all of the students (Benson \& Brack, 2010). The present study revealed that the teachers agreed that online assessment improved their knowledge about language assessment. The following quotes were extracted from teachers' interviews:

T3:"By conducting the online assessment, I learned something new to develop language assessment. The test or instruction was more organized. It helps me in giving a score and makes it more transparent. I could apply other types of language assessments such as peer-assessment and authentic assessment". 
Elshawa et al. (2016) pinpoint the harmful effects of being assessment illiterate for both teachers and students. It raised teachers' awareness about how to conduct language assessment creatively but still offers equal opportunity in terms of students' internet or gadget availability. Teachers found it easier to organize the assessment because of the sophisticated feature of the online platforms. The online environment offers excellent opportunities for contextualizing and differentiating assessment approaches (Benson \& Brack, 2010). It offered a bigger chance to have an authentic assessment. A test will have a positive impact if it includes authentic, real-life examples of the kind of tasks that the learners would have to perform in the future (Benson \& Brack (2010). It is especially applicable to online assessment since the environment provides authentic resources and tools for completing tasks and the process, as well as the product, can be observed by the evaluator (Benson \& Brack, 2010).

In addition to the positive effects of online assessment in IC Program, negative effects also emerge. It is defined as unwilling effects on teaching and learning, such as the exercise of assessment strategies rather than learning activities, excessive test anxiety, and failure to encourage general understanding (Alderson \& Wall, 1993; Cheng et. al 2004). The following are the negative effects that emerged from online assessments in IC program. The findings show that both teachers and students have the same confidence about technical things. All of them agree the things that make them worry most is the internet connection during the test. Teachers are worried about the misinterpretation of test scores and students' abilities (lack of rich information); this brings negative effects to the students.

\section{The complication of assessment administration}

The data obtained from the interview revealed that they faced several difficulties in conducting the online assessment. It has several shortcomings, for instance, dealing with technology, both teacher and students should have a strong internet connection. Furthermore, there might be misinterpretation among them, because students could not clarify directly what they have not been clear. Dealing with time management, students did not pay attention entirely to the online assessment. As a result, this assessment influenced teaching and learning (Alderson \& Wall, 1993).

Teacher 3; "When it comes to design, we can't equate it with offline, because if the offline test takes the form of all entries. Whereas online, to be honest, if all the tests are essay, the correction will be hard. So in the end we figured out that there were multiple choice of several parts, then the contents were only 5 ".

Different from Spivey and McMillan (2014) finding that students have neither study efforts nor course performance influenced by the testing procedure. This study revealed how teachers need to learn many things to be able to adjust to the technology. The full online assessment is relatively new for every educators because of the covid-19 outbreak. Teachers have taken so much time to master some different online testing applications to make the teaching and testing vary and interesting besides the university's main and formal e-learning platform. In fact, students of IC program are in agreement with the teachers. Online assessment make them worry over the instruction they do not understand, it is like one of the students statement 
S2: "In my opinion, the online test model from IC is good enough, but in the part of making WH-questions, students are asked to answer using lowercase letters. All are worried, in terms of implementation. I think the answers from the students also need to be corrected again by the lecturers, especially in the WH question part because maybe some students answered correctly but it is not at the system.

To sum up, accuracy and precision are worth in online assessment, especially if the test is in the form of a short answer test that demands the answer be the same as the existing answer key. The teachers struggle to fulfil it when making questions, and students should understand this condition.

S6: "The difficulties I found in the online assessment are the internet, supporting apps, and gadgets."

S4: "I am not confidence in doing the test because of my internet connection"

Almost all participants both teachers and students mention this topic in their answers. As have been mentioned earlier, connections highly determine the success of online assessment (Mohamadi, 2018; Spivey \& McMillan, 2014; Wang et al., 2014; Wihastyanang \& Latief, 2018). Besides, the most appropriate application used became an important issue. Teachers become frustrated because of a category: mastery of teaching technology. Teachers need to master the technology first before using it to make an online assessment.

\section{Lower engagement between teacher and students}

Both teachers and students had a lower engagement in online assessment. It might happen because there was no direct interaction. When teachers use their motivating teaching behavior, it would make the students show the highest levels of involvement. In contrast, in lessons where students were the least involved, teachers showed higher levels of disorganized teaching behaviors. Therefore, there are significant correlations between motivating teaching behaviors and student involvement. As one of the teachers clarified that in classroom interactions, she could directly observe and control her students. Furthermore, direct interactions might also prevent miscommunication. To engage students in online assessment, one of the teachers gave a short explanation related to how the material will be assessed and motivated them:

T2: "I think the easier way is offline because we can give instructions, control, and observe our students directly. And it will help us from miscommunication. I gave a short explanation related to how the material will be assessed and giving motivation to all my students."

Generally, online assessment is a new occurrence for the students. As a result, no wonder if it has not run well. Online learning reduces the so-called intense interaction between teachers and learners. As Obasa et al. (2013) mentioned that the chance to see teachers in real-time brings to the sense of learning and belonging. However, being able to engage with the teaching-learning process during online being the next challenge for both teachers and learners in language online learning. 


\section{Anxiety in English Test}

Test anxiety can be caused by several reasons. The flexibility of online assessment makes the students do the test everytime and everywhere. Students have less anxiety in doing the test since they did not get direct supervision. Theoretically, it is good to do a test when they do not have high anxiety (Aydin et al.,2006). However, teachers might have anxiety about their performance. The data taken from the interview revealed that teachers had anxiety about students' test, especially in avoiding cheating in online assessment and teaching:

T2: "I was also anxious when I instructed the students, I tried to make good rules to avoid cheating, yet I still worried about that".

Meanwhile, the result is different from how students feel anxious in the test. It was interesting to notice that students with high score in the mid-term test have the same anxiety when the test is offline. This anxiety comes up because of technical things, and this also brings them to do the test carefully.

$\mathrm{S}_{4}:$ "In my opinion, the online exam is more relaxed because sometimes you can do other things like eat, drink".

However, students with lower score mentioned that they did the test witout being afraid of having too many mistakes although they also do not feel sure with their internet connection. They thought that doing an online test is very flexible in terms of time and looking at the notes or references. This statement is in agreement with the result from the questionnaire.

S2: "I am not confident in doing the test because of my internet connection and the time limitation. I need to do it as quick as possible so that if there is a problem with the internet, the test had been finished well"

This is different from what Aydin et.al (2006) explain that test anxiety induces physical and psychological problems, adversely impacts confidence, focus and success, increases learning process mistakes, inhibits their actual output from being translated to test results and training successfully, and reduces interest in language learning. Meanwhile, the online assessment did not make students anxious in testing due to the lack of control.

\subsection{How the positive and negative effects emerge from online assessment in the EFL classroom}

From the students perspective, first students mention that he does not feel nervous at all in doing the online test because he was not directly supervised by the lecturer, it makes him relax. As his statement "Doing the test without direct teachers' supervision (online) does not make me nervous". However the negative effect being consensus is the internet connection factor, supportive gadget and laptop and not on the student learning.

S5: "Regarding the level of concern about time-limited online exams, worrying about signal constraints, cellphones / laptops suddenly shutting down, internet quota suddenly runs out, when the exam is not over and it makes the mood bad, so that once the signal has returned but we becomes unfocused, finally hurriedly hurry, it can even be blank. And sometimes questions that have been reworked again from the beginning due to the signal interference, and of course the lecturer must have permission to repeat the exam from the beginning. 
From the teachers' perspective, positive effects appear since they have together with the students reviewed all materials being tested a week earlier.

T3: "The positive effect can be caused by some ways teachers and students face the online test in the classroom. 1) Raise teacher-learner relationships 2) preparing the worst possibility, like internet connection, teachers let students tell the teachers at the beginning that all of them have been ready for the test,. 3) give a chance to retake the test if there is technical problems.

While Ali and Hamid (2020) explore some factors on negative effects of assessment, this study proved that online assessment does not always bring so much difficulty in language test.

\subsection{Students and teachers' readiness in preparing for the online test, teaching and learning process}

AfL stresses achievement and progress while fostering motivation. In an AfL classroom, students believe it is normal to make mistakes, because the learning environment is healthy. This is particularly important in the L2 classroom. Given that L2 students are keen to get input on their errors, de-emphasizing mistakes and offering feedback on specific errors are positive ways for teachers to foster a classroom atmosphere in which mistakes are not a big issue. Instead, teachers should create techniques and resources based on evidence obtained from assessments to support students in developing basic facets of their grammar. Teachers, for example, will fine-tune their training by designing learning experiences or lessons on certain grammatical objects if evaluations suggest that students struggle with them.

Teachers and students could communicate about what aspects of the skill needed to be improved. Teachers could give feedback for every students' work which is usually hard to do in the offline assessment because of the time limitation. At the end of the day, the interaction between teachers and students would be built through an online assessment.

T1: As usual, apart from the children in group discussion (I gave 30-60 minutes), in class I usually practice more questions besides those in the IC book, sometimes I give links like Oxford $n$ British grammar, to see explanations and practice questions other.

T2: InshaAllah there is improvement, ma'am. We emphasize the questions that are considered difficult and explain them in class, for example from the results of a quiz or training, most of them are weak in what parts. So that part would often appear in our daily teaching.

This finding is in line with a research mentions that teachers would focus more on the materials that students do not achieve well (Ridgway \& Mccusker, 2004). Moreover, feedback is given to increase learners from the current trajectory (Ridgway \& Mccusker, 2004). As mentioned in ARG (2002), the ten principles of AfL that they have been commonly used as guides for maintaining the advantages of instruction, they have remained at the theoretical stage where teachers in the classroom do not know how to operationalize them in their practice. Inherently, the vital role of appraisal in the classroom experience, the inextricable relationship of $A f L$ to learning by prompt and constructive input, and the active involvement of learners in evaluation for the purpose of learning improvement are at the forefront of these 
values. The ideals also encourage teachers to be adequately trained in order to translate these dreams into realities in the classroom and to direct students towards their learning objectives.

\section{Conclusion}

By providing an investigation on the effects of an online test, the present study fills the void. This current study found that during the Covid-19 outbreak, the online evaluation in EFL Indonesian classrooms, especially in IC program created both negative effects and positive ones. In general, the students show positive attitudes toward the use of online assessment. The effects were seen from enhancing the flexibility of assessment, building awareness of preparing online language assessment, improving language assessment knowledge, building students autonomous learning, the complication of assessment administration, lower engagement between teacher and students, and anxiety in English tests. Online language assessment is a bit new challenging for EFL teachers and students. Giving some difficulty in producing the test does not make EFL teachers give up on doing the online test. Moreover, students could also learn from their mistakes since everything can be recorded well. The key drawback of this research is the limited number of participants, which limits the generalizability of the results to the unique background of this study. As a result, since full online assessment is relatively new in this country, it is proposed that more studies with a wider sample and more supporting documents should be carried out to make accurate generalizations about the effects of the online evaluation. Besides, this study proposes penalties for teachers in a more structured way to plan the task. Teachers could also discuss several types of new language assessment forms in the online evaluation. Test developers should consider the potential negative as well as the positive effect of the test they are designing on teaching and learning, and it is definitely a smart thing to do to try to engineer positive effects via test design.

\section{References}

Alderson, J. C., \& Wall, D. (1993). Does washback exist? Applied Linguistics, 14(2), 115-129. https://doi.org/10.1093/applin/14.2.115

Ali, Md. M., \& Hamid, M. O. (2020). Teaching English to the test: Why does negative washback exist within secondary education in Bangladesh? Language Assessment Quarterly, 17(2), 129-146. https://doi.org/10.1080/15434303.2020.1717495

Ali, Z. (2015). A case study of tertiary students "experiences using Edmodo in language learning. International Journal of Language Education and Applied Linguistics (IJLEAL) Copyright ( Penerbit Universiti Malaysia Pahang Print, 2289-9294 Online, 2(2015), 39-48.

Assessment Reform Group. (2002). Assessment for learning: 10 principles. Cambridge University Press.

Aydin, D. S., Yavuz, D. F., \& Yeşilyurt, S. (2006). Test anxiety in foreign language learning. 17.

Bailey, K. M. (1996). Working for washback: A review of the washback concept in language testing. Language Testing, 13(3), 257-279. https://doi.org/10.1177/026553229601300303

Baksh, A. (2016). Washback effect of school-based English language assessment: a casestudy on students' perceptions. Social Science and Humanities, Pertanika UPM, 24(3), 18. 
Benson, R., \& Brack, C. (2010). Online learning and assessment in higher education; A planning guide. Chandos Publishing.

Cai, H. (2012). E-learning and English teaching. IERI Procedia, 2, 841-846. https://doi.org/10.1016/j.ieri.2012.06.180

Cassady, J. C., \& Gridley, B. E. (2005). The Effects of online formative and summative assessment on test anxiety and performance. The Journal of Technology, Learning and Assessment, 4(1), 31.

Cheng, L., Rogers,T \& Hu, H., (2004). ESL/EFL instructors' classroom assessment practices: purposes, methods, and procedures., Language Testing, 21(3), 360-389

Cheng, L., Andrews, S., \& Yu, Y. (2011). Impact and consequences of school-based assessment (SBA): Students' and parents' views of SBA in Hong Kong. Language Testing, 28(2), 221-249. https://doi.org/10.1177/0265532210384253

Cheng, L., Sun, Y., \& Ma, J. (2015). Review of washback research literature within Kane's argument-based validation framework. Language Teaching, 48(4), 436-470. https://doi.org/10.1017/S0261444815000233

Cox, T. L., Malone, M. E., \& Winke, P. (2018). Future directions in assessment: Influences of standards and implications for language learning. Foreign Language Annals, 51(1), 104115. https://doi.org/10.1111/flan.12326

Daniels, M., Sarte, E., \& Cruz, J. D. (2019). Students' perception on e-learning: A basis for the development of e-learning framework in higher education institutions. IOP Conference Series: Materials Science and Engineering, 482, 012008. https://doi.org/10.1088/1757$899 X / 482 / 1 / 012008$

Doculan, J. (2016). E-Learning readiness assessment tool for Philippine higher education institutions. International Journal on Integrating Technology in Education (IJITE). https://doi.org/10.5121/ijite.2016.5203

Elshawa, N. R. M., Heng, C. S., \& Abdullah, A. N. (2016). Teachers' assessment literacy and washback effect of assessment. International Journal of Applied Linguistics and English Literature, 5(4). https://doi.org/10.7575/aiac.ijalel.v.5n.4p.135

Fan, J., Ji, P., \& Song, X. (2014). Washback of university-based English language tests on students' learning: A case study. The Asian Journal of Applied Linguistics, 1(2), 178-191.

Furaidah, F., Saukah, A., \& Widiati, U. (2015). Washback of English national examination in the Indonesian Context. TEFLIN Journal - A Publication on the Teaching and Learning of English, 26(1), 36. https://doi.org/10.15639/teflinjournal.v26i1/36-58

Galikyan, I., Madyarov, I., \& Gasparyan, R. (2019). Student Test Takers' and Teachers' Perceptions of the TOEFL Junior ${ }^{\circledR}$ Standard Test. ETS Research Report Series, 2019(1), 115. https://doi.org/10.1002/ets2.12264

Genesee, F., \& Upshur, J. A. (1996). Classroom-based evaluation in second language education. Cambridge University Press.

Green, A. (2013). Washback in language assessment. International Journal of English Studies, 13(2), 39-51. https://doi.org/10.6018/ijes.13.2.185891

Ha, N. T. T. (2019). A Literature Review of Washback Effects of Assessment on Language Learning. Journal of Science Ho Chi Minh City Open University, 9(5), 3-15.

Hakim, L. N. (2018). Washback effect in language testing: what do we know and what is its effect? Jurnal Forum Didaktik, 2(1), 10.

Han, J. H., \& Finkelstein, A. (2013). Understanding the effects of professors' pedagogical development with Clicker Assessment and Feedback technologies and the impact on 
students' engagement and learning in higher education. Computers \& Education, 65, 6476. https://doi.org/10.1016/j.compedu.2013.02.002

Hashimov, E. (2015). Qualitative data analysis: a methods sourcebook and the coding manual for qualitative researchers. Technical Communication Quarterly, 24(1), 109-112. https://doi.org/10.1080/10572252.2015.975966

Johnson, M., \& Shaw, S. (2019). What is computer-based testing washback, how can it be evaluated and how can this support practitioner research? Journal of Further and Higher Education, 43(9), 1255-1270. https://doi.org/10.1080/0309877X.2018.1471127

Kilickaya, F. (2016). Washback effects of a high-stakes exam on lower secondary school English teachers' practices in the classroom. Lublin Studies in Modern Languages and Literature, 40(1), 116-134.

Lee, I. (2007). Assessment for learning: integrating assessment, teaching, and learning in the ESL/EFL writing classroom. Canadian Modern Language Review, 64(1), 199-213. https://doi.org/10.3138/cmlr.64.1.199

McKinley, J., \& Thompson, G. (2018). Washback effect in teaching English as an international language. In J. I. Liontas, T. International Association, \& M. DelliCarpini (Eds.), The TESOL Encyclopedia of English Language Teaching (pp. 1-12). John Wiley \& Sons, Inc. https://doi.org/10.1002/9781118784235.eelto656

Mohamadi, Z. (2018a). Comparative effect of online summative and formative assessment on EFL student writing ability. Studies in Educational Evaluation, 59, 29-40. https://doi.org/10.1016/j.stueduc.2018.02.003

Obasa, A. I., Eludire, A. A., \& Ajao, T. A. (2013). A comparative study of synchronous and asynchronous e-learning resources. International Journal of Innovative Research in Science, Engineering and Technology, 2(11), 5938-5946.

Rahman, Abd. (2018). Building autonomous learners in English as a foreign language (EFL) Classroom. Proceedings of the International Conference on Education in Muslim Society (ICEMS 2017). International Conference on Education in Muslim Society (ICEMS 2017), Banten, Indonesia. https://doi.org/10.2991/icems-17.2018.44

Ridgway, J., \& Mccusker, S. (2004). Literature review of e-assessment. Futurelab.

Şenel, E., \& Tutunis, B. (2013). The washback effect of testing on students' learning in efl writing classes. Humanising Language Teaching, 1775-9715, 2013. https://doi.org/10.1501/Dilder_0000000154

Spivey, M. F., \& McMillan, J. J. (2014). classroom versus online assessment. Journal of Education for Business, 89(8), 450-456. https://doi.org/10.1080/08832323.2014.937676

Sundayana, W., Meekaeo, P., Purnawarman, P., \& Sukyadi, D. (2018). Washback of English national exams at ninth-grade level in Thailand and Indonesia. Indonesian Journal of Applied Linguistics, 8(1). https://doi.org/10.17509/ijal.v8i1.11478

Suryoputro, G. (2016). Exploring EFL students' perceptions of washback of portfolios in reading assessment. International Journal of Language and Linguistics, 3(2), 6.

Wang, C., Yan, J., \& Liu, B. (2014). An empirical study on washback effects of the internetbased college English test band 4 in China. English Language Teaching, 7(6), p26. https://doi.org/10.5539/elt.v7n6p26

Wihastyanang, W. D., \& Latief, M. A. (2018). The impact of electronic feedback on students' writing quality. The Online Journal of New Horizons in Education, 8(4), 8. 
Xu, Q., \& Liu, J. (2018a). A study on the washback effects of the test for English majors (tem): implications for testing and teaching reforms. Springer Singapore. https://doi.org/10.1007/978-981-13-1963-1

$\mathrm{Xu}, \mathrm{Q}$., \& Liu, J. (2018b). A study on the washback effects of the test for English majors (TEM): Implications for Testing and Teaching Reforms. Springer Singapore. https://doi.org/10.1007/978-981-13-1963-1

Yorke, M. (2003). Formative assessment in higher education: Moves towards theory and the enhancement of pedagogic practice. Higher Education, 45, 477-501. https://doi.org/10.1023/A:1023967026413

Zhan, Y., \& Andrews, S. (2014). Washback effects from a high-stakes examination on out-ofclass English learning: Insights from possible self theories. Assessment in Education: Principles, Policy \& Practice, 21(1), 71-89. https://doi.org/10.1080/0969594X.2012.757546 